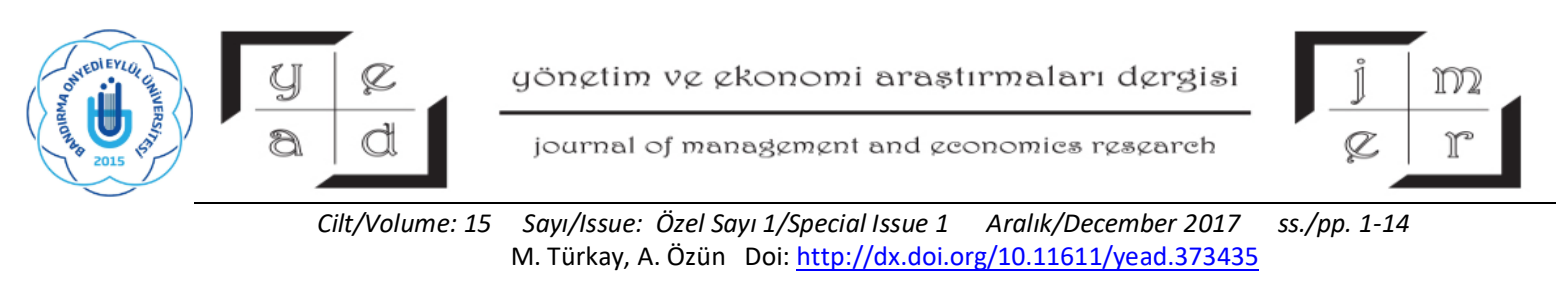

\title{
A MARKOV AUTOREGRESSIVE DYNAMIC CAUSALITY ANALYSIS FOR WORLD EQUITY MARKETS IN CRISIS PERIOD ${ }^{1}$
}

\author{
Dr. Mesut TÜRKAY ${ }^{2 *}$ iD \\ Assoc. Prof. Alper ÖZÜN** iD
}

\begin{abstract}
We apply the Markov process for causality analysis proposed by Psaradakis et al. (2005) on world equity markets. By estimating a Markov switching autoregression model, we test the existence of a dynamic causality relationship between major equity indices. The empirical evidence shows that the proposed dynamic model successfully captures the causality relationship in equity markets controlling for the global volatility (VIX) index in crisis periods. The research has originality in applying Markov switching autoregression model in equity markets and also providing recent empirical evidence on causality relationships in equity markets in crisis periods.
\end{abstract}

Key Words: Equity Markets, Causality, Markov Models, Financial Crisis

JEL Classification: G12, C4, G17

\section{DÜNYA BORSALARININ KRİZ DÖNEMINDEKİ MARKOV OTOREGRESIF NEDENSELLİK ANALIZí}

\begin{abstract}
ÖZ
Çalışmada, dünya borsaları arasındaki nedensellik Psaradakis (2005) tarafindan ortaya atılan Markov süreciyle analiz edilmektedir. Markov değişim otoregresif modeli tahmin edilerek önde gelen borsalar arasındaki dinamik nedensellik ilişkisinin varlığı test edilmektedir. Ampirik bulgular önerilen dinamik modelin borsalar arasındaki ilişkiyi kriz dönemlerindeki küresel oynaklı̆̆l kontrol ederek başarılı bir şekilde gösterdiğine işaret etmektedir. Çalışma, borsalara Markov değişim otoregresif

\footnotetext{
${ }^{1}$ The first draft of this paper is presented ICOAEF 2017 conferance on 06-07 December 2017

${ }^{2}$ Corresponding Author. The views represented in this paper are those of the authors and do not necessarily reflect the positions or policies of the Undersecretariat of Treasury

*Undersecretariat of Treasury, Republic of Turkey, Ankara, Turkey, mesut.turkay@ hazine.gov.tr

${ }^{* *}$ University of Greenwich, School of Business, London, UK, alper.ozun@ hotmail.com
} 
Yönetim ve Ekonomi Arastırmaları Dergisi / Journal of Management and Economics Research

Cilt/Volume: 15 Sayı/Issue: Özel Sayı 1/Special Issue 1 Aralık/December 2017 ss./pp. 1-14

M. Türkay, A. Özün Doi: http://dx.doi.org/10.11611/yead.373435

modelinin uygulanması ve kriz dönemlerinde borsalar arasındaki nedensellik ilişkisine yönelik ampirik bulgular sunması açılarından orijinallik taşımaktadır.

Anahtar Kelimeler: Borsalar, Nedensellik, Markov Modelleri, Finansal Krizler

\section{Jel Siniflandirmast: G12, C4, G17}

\section{INTRODUCTION}

Causality relationship is not always stable. Most of the time, the results of the causality tests are sensitive to the period considered, in other words, they are time dependent. In these cases, traditional Granger (1969) methodology is biased. As a solution, Psaradakis et al. (2005) proposed employing a vector autoregressive (VAR) model with time varying parameters for analyzing Granger causality. According to their approach, it is assumed that the number and location of points at which causality changes are not known. That is why, changes in causality are considered as random events managed by unobservable Markov chain and let the data choose these points. The parameters of the Markov switching vector autoregression model change according to the presence and direction of the Granger causality in this model.

In this empirical research, we apply the Markov regime switching causality methodology proposed by Psaradakis et al. (2005) to analyze the causality relationship between DOW, DAX and NIKKEI index returns controlling for the VIX index. We perform the empirical investigation with daily data for the US (DOW), German (DAX) and Japanese (NIKKEI) equity indices covering the period from 2000 to 2013.

There are two main motivations in our research. Firstly, we want to apply the Markov switching autoregressive model into equity markets to seek for existence of a dynamic causality relationship among the equity markets. In this sense, our motivation is to apply a dynamic mathematical model to finance to propose a new framework for research in causality relationships in financial markets. Secondly, we want to examine the causality relationship in major equity indices in the crisis period under regime switching process and compare the results with stable periods.

The empirical results of our analysis show that there is an overall causality relationship from DOW to DAX. The causality is lower in the relatively stable periods between 2004 and 2007. However, it increases during the global financial crisis in 2008, and we observe an increasing co-movement and stronger causality from DOW to DAX in the post-crisis period. More specifically, causality from DOW to DAX strengthened after the announcement of FED chair in May 2013 that they can start unwinding extraordinary monetary stimulus. 
Yönetim ve Ekonomi Araștırmaları Dergisi / Journal of Management and Economics Research

Cilt/Volume: 15 Sayı/Issue: Özel Sayı 1/Special Issue 1 Aralık/December 2017 ss./pp. 1-14

M. Türkay, A. Özün Doi: http://dx.doi.org/10.11611/yead.373435

When we examine the causality from DOW return to NIKKEI return, we find out the empirical fact that DOW return Granger causes NIKKEI return, but it is time-varying. Causality from DOW to NIKKEI is weak between 2000 and 2003 but is stronger between 2004 and 2007. The higher causality can be a result of financial volatility in Japan in 2006. Causality seems to be weak in the global financial crisis period but increases thereafter. In addition, the causality from DOW to NIKKEI is lower as compared to that to DAX.

In the next part, we provide a short but recent literature review on causality relationship in financial markets. In the third part, we introduce the data and provide a methodological background for the empirical tests. In the fourth part, the empirical tests are performed; the results are presented and discussed. The paper ends with a conclusion where the empirical findings are discussed from practical finance perspective and some suggestions are proposed for the future research.

\section{LITERATURE REVIEW}

Due to economic and financial globalization, interdependence between stock markets has increased in the last decades. Especially with the stock market crash of 1987 in US and several emerging market crisis in 1990s' such as Mexican, Asian and Russian financial crisis, there has been a growing interest on the relationship between equity markets in different countries. As a result, many studies emerged in this area and formed a rich literature.

One group of the literature analyzes stock market integration and co-movement of equity indices. Cointegration is one of the most commonly used methods to find out whether stock markets are related in the long run. Several studies such as Kasa (1992), Arshanapalli and Doukas (1993), Masih and Masih (1997, 1999), Francis and Leachman (1998), Ahlgren and Antell (2002), and Syriopoulos (2004, 2007) found that stock markets are interdependent and there is a long term relationship between them. On the other hand, other studies such as Kanas (1998), Huang et al. (2000), Climent and Meneu (2003), Gupta and Guidi (2012), Zhang and $\mathrm{Li} \mathrm{(2014)} \mathrm{argue} \mathrm{that} \mathrm{there} \mathrm{is} \mathrm{no} \mathrm{co-integration.} \mathrm{In} \mathrm{order} \mathrm{to} \mathrm{find} \mathrm{out} \mathrm{whether}$ stock markets are interrelated, some other studies such as Becker et al. (1990) and Longin and Solnik (2001) use correlation and covariance to analyze the co-movement of equity markets. As a consequence of increasing integration among countries, some other studies such as Longin and Solnik (1995), Lee (2005), Morana and Beltratti (2008), Quinnand Voth (2008) and Ye (2014) argue that stock markets in different parts of the world are becoming more and more correlated.

Another part of the literature focus on the causality and lead-lag relationships among major stock exchanges. Early studies about the causality between national stock markets employed linear models such as granger causality, ordinary VAR and vector error correction. This literature includes 
Yönetim ve Ekonomi Araștırmaları Dergisi / Journal of Management and Economics Research

Cilt/Volume: 15 Sayı/Issue: Özel Sayı 1/Special Issue 1 Aralık/December 2017 ss./pp. 1-14

M. Türkay, A. Özün Doi: http://dx.doi.org/10.11611/yead.373435

Eun and Shim (1989), Malliaris and Urrutia (1992), Hamori and Imamura (2000), Narayan et al. (2004) and Wang (2014) among others.

Since the article of Baek and Brock (1992), there has been an increasing interest in studying nonlinear dynamic relations between time series. More recently, a new and developing literature consisting of studies using nonlinear models to analyze the relationships between stock markets emerged. Ozdemir and Cakan (2007), Gooijer and Sivarajasingham (2008), Beine et al. (2008), Hatemi (2012) and Caraiani (2012) are among them. The number and diversity of articles using nonlinear models are still limited and this is one of the motivations of our study.

The literature on the relationship between stock exchanges is not limited to the studies mentioned above. Some others used different methods to analyze the integration and comovement of stock markets around the world. Among them, Bessler and Yang (2003) used directed acyclic graphs, Rua and Nunes (2009) wavelet analysis, Asgharian et al. (2013) spatial analysis and Liu (2013) dynamic panel-data gravity model.

Within our knowledge, the Markov autoregressive process has not been applied before for the existence of causality relationship between the stock markets. In the following chapter, we show how to apply the process for the equity markets in the crisis period.

\section{MATERIALS AND METHODOLOGY}

We perform our empirical investigation with daily data for DOW, DAX and NIKKEI indices covering the period from 2000 to 2013. Data are obtained from Bloomberg. We measure the return of indices in period $t$, by the first difference of the logarithm. We estimate the Markov switching vector autoregression model in equation (1) to explore the causality between $Y_{1, t}$ and $Y_{2, t}$ conditionally on VIX which is denoted as $\left\{V_{t}\right\}$.

$\left[\begin{array}{l}Y_{1, t} \\ Y_{2, t}\end{array}\right]=\left[\begin{array}{l}\mu_{10}\left(1-S_{1, t}\right)+\mu_{11} S_{1, t} \\ \mu_{20}\left(1-S_{2, t}\right)+\mu_{21} S_{2, t}\end{array}\right]+$

$\sum_{k=1}^{h_{1}}\left[\begin{array}{cc}\phi_{10}^{(k)}\left(1-S_{1, t}\right)+\phi_{11}^{(k)} S_{1, t} & \gamma_{1}^{(k)} S_{1, t} \\ \gamma_{2}^{(k)} S_{2, t} & \phi_{20}^{(k)}\left(1-S_{2, t}\right)+\phi_{21}^{(k)} S_{2, t}\end{array}\right]\left[\begin{array}{l}Y_{1, t-k} \\ Y_{2, t-k}\end{array}\right]+$

$\sum_{k=1}^{h_{2}}\left[\begin{array}{l}\theta_{10}^{(k)}\left(1-S_{1, t}\right)+\theta_{11}^{(k)} S_{1, t} \\ \theta_{20}^{(k)}\left(1-S_{2, t}\right)+\theta_{21}^{(k)} S_{2, t}\end{array}\right] V_{t-k}+\left[\begin{array}{c}\varepsilon_{1, t} \\ \varepsilon_{2, t}\end{array}\right], \mathrm{t}=1,2, \ldots, \mathrm{T}$.

In this formulation, $S_{1, t}$ and $S_{2, t}$ are latent state variables. They take values of 0 or 1 at time $\mathrm{t}$ conditional on the regime. $\varepsilon_{t}^{\prime}=\left[\varepsilon_{1},: \varepsilon_{2}, t\right]$ is a white noise process independent of $S_{1, t}$ and $S_{2, t}$ with mean zero and covariance matrix which depends on $S_{1, t}$ and $S_{2, t}$. We have four alternative states of nature: 


$$
S_{t}=\left\{\begin{array}{l}
1 \text { if } S_{1, t}=1 \text { and } S_{2, t}=1, \\
2 \text { if } S_{1, t}=0 \text { and } S_{2, t}=1, \\
3 \text { if } S_{1, t}=1 \text { and } S_{2, t}=0, \\
4 \text { if } S_{1, t}=0 \text { and } S_{2, t}=0 .
\end{array}\right.
$$

Therefore, the model in (1) indicates that:

$$
\begin{aligned}
& {\left[\begin{array}{l}
Y_{1, t} \\
Y_{2, t}
\end{array}\right]=\left[\begin{array}{l}
\mu_{11} \\
\mu_{21}
\end{array}\right]+\sum_{k=1}^{h_{1}}\left[\begin{array}{ll}
\phi_{11}^{(k)} & \gamma_{1}^{(k)} \\
\gamma_{2}^{(k)} & \phi_{21}^{(k)}
\end{array}\right]\left[\begin{array}{l}
Y_{1, t-k} \\
Y_{2, t-k}
\end{array}\right]+\sum_{k=1}^{h_{2}}\left[\begin{array}{l}
\theta_{11}^{(k)} \\
\theta_{21}^{(k)}
\end{array}\right] V_{t-k}+\left[\begin{array}{l}
\varepsilon_{1, t} \\
\varepsilon_{2, t}
\end{array}\right], \text { if } S_{t}=1,} \\
& {\left[\begin{array}{l}
Y_{1, t} \\
Y_{2, t}
\end{array}\right]=\left[\begin{array}{l}
\mu_{10} \\
\mu_{21}
\end{array}\right]+\sum_{k=1}^{h_{1}}\left[\begin{array}{cc}
\phi_{10}^{(k)} & 0 \\
\gamma_{2}^{(k)} & \phi_{21}^{(k)}
\end{array}\right]\left[\begin{array}{l}
Y_{1, t-k} \\
Y_{2, t-k}
\end{array}\right]+\sum_{k=1}^{h_{2}}\left[\begin{array}{l}
\theta_{10}^{(k)} \\
\theta_{21}^{(k)}
\end{array}\right] V_{t-k}+\left[\begin{array}{l}
\varepsilon_{1, t} \\
\varepsilon_{2, t}
\end{array}\right], \text { if } S_{t}=2,} \\
& {\left[\begin{array}{l}
Y_{1, t} \\
Y_{2, t}
\end{array}\right]=\left[\begin{array}{l}
\mu_{11} \\
\mu_{20}
\end{array}\right]+\sum_{k=1}^{h_{1}}\left[\begin{array}{cc}
\phi_{11}^{(k)} & \gamma_{1}^{(k)} \\
0 & \phi_{20}^{(k)}
\end{array}\right]\left[\begin{array}{l}
Y_{1, t-k} \\
Y_{2, t-k}
\end{array}\right]+\sum_{k=1}^{h_{2}}\left[\begin{array}{l}
\theta_{11}^{(k)} \\
\theta_{20}^{(k)}
\end{array}\right] V_{t-k}+\left[\begin{array}{l}
\varepsilon_{1, t} \\
\varepsilon_{2, t}
\end{array}\right], \text { if } S_{t}=3,} \\
& {\left[\begin{array}{l}
Y_{1, t} \\
Y_{2, t}
\end{array}\right]=\left[\begin{array}{l}
\mu_{10} \\
\mu_{20}
\end{array}\right]+\sum_{k=1}^{h_{1}}\left[\begin{array}{cc}
\phi_{10}^{(k)} & 0 \\
0 & \phi_{20}^{(k)}
\end{array}\right]\left[\begin{array}{l}
Y_{1, t-k} \\
Y_{2, t-k}
\end{array}\right]+\sum_{k=1}^{h_{2}}\left[\begin{array}{l}
\theta_{10}^{(k)} \\
\theta_{20}^{(k)}
\end{array}\right] V_{t-k}+\left[\begin{array}{l}
\varepsilon_{1, t} \\
\varepsilon_{2, t}
\end{array}\right], \text { if } S_{t}=4,}
\end{aligned}
$$

The regime indicators $S_{1, t}$ and $S_{2, t}$ define the causality patterns in the model. In this respect, $S_{1, t}$ shows whether $Y_{2, t}$ Granger causes $Y_{1, t}$ and $S_{2, t}$ shows whether $Y_{1, t}$ Granger causes $Y_{2, t}$. Given that at least one of the $\gamma_{1}^{(1)}, \ldots, \gamma_{1}^{h_{1}}$ is not equal to zero, $Y_{2, t}$ is Granger causal for $Y_{1, t}$ when $S_{1, t}=1$ (if $S_{t}=1$ or $S_{t}=3$ ) and is not Granger causal for $Y_{1, t}$ when $S_{1, t}=0$ (if $S_{t}=2$ or $S_{t}=4$ ). In the same way, $Y_{1, t}$ is Granger causal for $Y_{2, t}$ when $S_{2, t}=1$ (if $S_{t}=1$ or $S_{t}=2$ ) given that at least one of the $\gamma_{2}^{(1)}, \ldots, \gamma_{2}^{h_{1}}$ is not equal to zero and is not Granger causal for $Y_{2, t}$ when $S_{2, t}=0$ (if $S_{t}=3$ or $S_{t}=4$ ). The covariance matrix of the disturbances of the model in equation (1) is stated as follows:

$$
\mathrm{E}=\left(\varepsilon_{t} \varepsilon_{t}^{\prime} \mid S_{t}=l\right)=\left[\sigma_{i j, l}\right], \mathrm{i}, \mathrm{j}=1,2 ; 1=1, \ldots, 4 \text {. }
$$

In this model specification, it is assumed that data selects the state of the system at period $t$ with a probability which depends on the state present at time $t$ - 1 . Henceforth, Psaradakis et al. (2005) propose that regime indicators are time homogenous and first-order Markov process with transition probabilities as follow:

$$
p_{i j}^{l}=P\left(S_{l, t+1}=j \mid S_{l, t}=i\right), \mathrm{i}=\mathrm{j}=0,1 ; 1=1,2 .
$$


Yönetim ve Ekonomi Araștırmaları Dergisi / Journal of Management and Economics Research

Cilt/Volume: 15 Sayı/Issue: Özel Sayı 1/Special Issue 1 Aralık/December 2017 ss./pp. 1-14

M. Türkay, A. Özün Doi: http://dx.doi.org/10.11611/yead.373435

Furthermore, $S_{1, t}$ and $S_{2, t}$ are assumed to be independent. The random process $S_{t}$ is defined as timehomogenous and has first order Markov chain with the following transition matrix where $\mathrm{P}$ states the stochastic matrix whose (i,j) component is the probability $\mathrm{P}\left(S_{l, t+1}=j \mid S_{l, t}=i\right)$ for $\mathrm{i}, \mathrm{j}=1, \ldots, 4$ :

$$
\mathrm{P}=\left[\begin{array}{cccc}
p_{11}^{(1)} p_{11}^{(2)} & p_{11}^{(2)}\left(1-p_{00}^{(1)}\right) & p_{11}^{(1)}\left(1-p_{00}^{(2)}\right) & \left(1-p_{00}^{(1)}\right)\left(1-p_{00}^{(2)}\right) \\
p_{11}^{(2)}\left(1-p_{11}^{(1)}\right) & p_{00}^{(1)} p_{11}^{(2)} & \left(1-p_{11}^{(1)}\right)\left(1-p_{00}^{(2)}\right) & p_{00}^{(1)}\left(1-p_{00}^{(2)}\right) \\
p_{11}^{(1)}\left(1-p_{11}^{(2)}\right) & \left(1-p_{00}^{(1)}\left(1-p_{11}^{(2)}\right)\right. & p_{11}^{(1)} p_{00}^{(2)} & p_{00}^{(2)}\left(1-p_{00}^{(1)}\right) \\
\left(1-p_{11}^{(1)}\right)\left(1-p_{11}^{(2)}\right) & p_{00}^{(1)}\left(1-p_{11}^{(2)}\right) & p_{00}^{(2)}\left(1-p_{11}^{(1)}\right) & p_{00}^{(1)} p_{00}^{(2)}
\end{array}\right]
$$

Causality analysis constructed on the Markov switching vector autoregression model in equation (1) is favorable for several reasons. The states in the model directly reflect the patterns of the causality between the variables and many changes in causality at different points are allowed. In addition, one can make probabilistic inferences about the points when the causality changes in this approach.

\section{EMPIRICAL RESULTS}

In order to investigate the Markov switching vector autoregression model to search the causal link between DOW-DAX and DOW-NIKKEI, we focus on the empirical evidence from the maximum likelihood estimation of the parameters of the Markov switching VAR model described in equation (1) for stock exchange pairs including DOW-DAX and DOW-NIKKEI.

\section{4. a. Dynamic causality between the US and German equity markets}

For DOW-DAX relationship, we found unidirectional Granger causality running from DOW to DAX. More specifically, the $\gamma_{1}{ }^{(1)}$ and $\gamma_{1}{ }^{(2)}$ in DOW equation are positive but not statistically significant. Hence, DAX return does not Granger causes DOW return when the economy is in $\mathrm{St}=1 \mathrm{or} \mathrm{St}=3$. That is, according to the empirical results DAX does not have predictive ability for DOW if $\mathrm{St}=1 \mathrm{or} \mathrm{St}=3$ prevails in the economy. Moreover, $\gamma_{2}{ }^{(1)}$ and $\gamma_{2}{ }^{(2)}$ in the DOW equation are positive and statistically significant at $1 \%$ level. In other words, DOW has predictive power for DAX while the economy is in $\mathrm{St}=1$ or $\mathrm{St}=2$.

Next, we examine the estimated filter probabilities that each related variable Granger-causes for the other one at each point in the sample period to understand the extent and timing of the changes in the causality relation over the sample period. We first plot the estimated filter probability of DOW Granger causing DAX in Figure 1. 
Yönetim ve Ekonomi Araștırmaları Dergisi / Journal of Management and Economics Research Cilt/Volume: 15 Sayı/Issue: Özel Sayı 1/Special Issue 1 Aralık/December 2017 ss./pp. 1-14 M. Türkay, A. Özün Doi: http://dx.doi.org/10.11611/yead.373435

Table 1: Estimates of Parameters of the Model for DOW and DAX

\begin{tabular}{|c|c|c|c|c|c|}
\hline Parameter & Estimate & Std. error & Parameter & Estimate & Std. error \\
\hline$p_{11}^{(I)}$ & $0.987 * * *$ & 0.005 & $p_{11}^{(2)}$ & $0.962 * * *$ & 0.008 \\
\hline$p_{00}^{(l)}$ & $0.996^{* * *}$ & 0.001 & $p_{00^{(2)}}$ & $0.941 * * *$ & 0.013 \\
\hline$\mu_{10}$ & $0.001 * * *$ & 0.000 & $\mu_{20}$ & $0.002 * * *$ & 0.000 \\
\hline$\mu_{11}$ & $-0.001 * * *$ & 0.001 & $\mu_{21}$ & $-0.000^{*}$ & 0.000 \\
\hline$\phi_{10^{(1)}}$ & $-0.066^{* * *}$ & 0.028 & $\phi_{20}{ }^{(1)}$ & $-0.110^{* * *}$ & 0.040 \\
\hline$\phi_{10^{(2)}}$ & $-0.020 * * *$ & 0.012 & $\phi_{20}^{(2)}$ & $-0.091^{*}$ & 0.030 \\
\hline$\phi_{11}^{(I)}$ & $-0.042 * * *$ & 0.016 & $\phi_{21}^{(I)}$ & $-0.214 * * *$ & 0.040 \\
\hline$\phi_{10^{(2)}}$ & -0.088 & 0.049 & $\phi_{2 I^{(2)}}$ & $-0.047 * * *$ & 0.030 \\
\hline$\gamma_{I}^{(1)}$ & $0.018 * * *$ & 0.011 & $\gamma_{2}{ }^{(l)}$ & $0.307 * * *$ & 0.063 \\
\hline$\gamma_{I}^{(2)}$ & $0.009 * * *$ & 0.018 & $\gamma_{2}^{(2)}$ & $0.066 * * *$ & 0.025 \\
\hline$\theta_{10^{(I)}}$ & $-0.002 * * *$ & 0.003 & $\theta_{20^{(l)}}$ & $-0.035^{* * *}$ & 0.007 \\
\hline$\theta_{10^{(2)}}$ & $-0.001 * *$ & 0.003 & $\theta_{20^{(2)}}$ & $-0.012 * * *$ & 0.008 \\
\hline$\theta_{1 I^{(1)}}$ & -0.035 & 0.007 & $\theta_{2 I^{(I)}}$ & $-0.015 * * *$ & 0.014 \\
\hline$\theta_{11}^{(2)}$ & -0.012 & 0.008 & $\theta_{2 I^{(2)}}$ & $-0.011 * * *$ & 0.005 \\
\hline$\sigma_{11}^{(1)}$ & $0.015^{*}$ & 0.001 & $\sigma_{22}(l)$ & $0.021 * * *$ & 0.001 \\
\hline$\sigma_{11}^{(2)}$ & $0.010 * * *$ & 0.000 & $\sigma_{22}^{(2)}$ & $0.013 * * *$ & 0.000 \\
\hline$\sigma_{11}^{(3)}$ & $0.033 * * *$ & 0.002 & $\sigma_{22}{ }^{(3)}$ & $0.040 * * *$ & 0.003 \\
\hline$\sigma_{11}^{(4)}$ & $0.005^{* * *}$ & 0.000 & $\sigma_{22}(4)$ & $0.007 * * *$ & 0.000 \\
\hline Log likelihood & 21394. & & & & \\
\hline
\end{tabular}

Notes: $*, * *, * * *$ denote significance at the $10 \%, 5 \%$ and $1 \%$ levels.

Figure 1:Filter Probability of DOW Return Granger-causing DAX Return

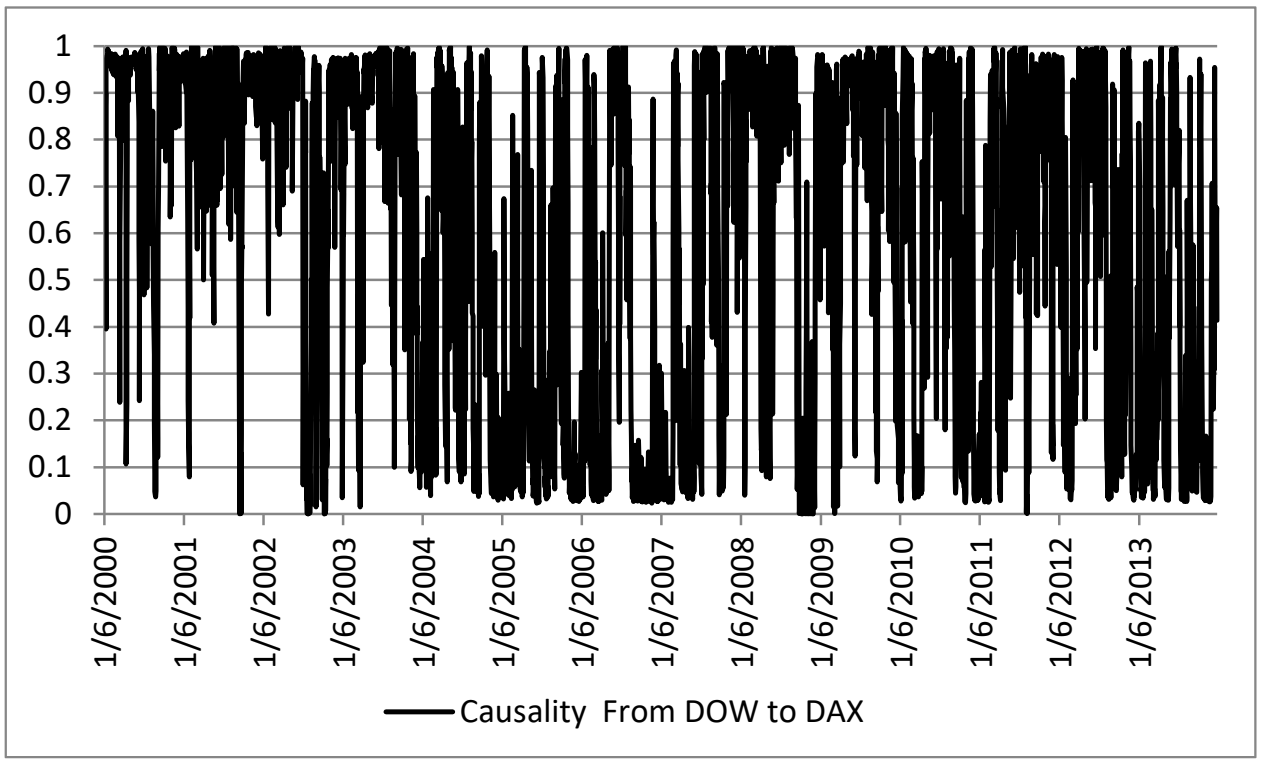


Yönetim ve Ekonomi Araștırmaları Dergisi / Journal of Management and Economics Research

Cilt/Volume: 15 Sayı/Issue: Özel Sayı 1/Special Issue 1 Aralık/December 2017 ss./pp. 1-14

M. Türkay, A. Özün Doi: http://dx.doi.org/10.11611/yead.373435

Figure 1 shows that the causality from DOW to DAX is usually high in the analysis period. This is consistent with the fact that US is the financial epicenter of the world. Looking at the subperiods, causality is low in the pre-crisis period between 2004 and 2007. In this period, US and German stockmarkets moved mostly according to their internal dynamics. However, causality from DOW to DAX increased with the global financial crisis in 2008. We observe increasing co-movement and stronger causality from DOW to DAX in the post-crisis period. More specifically, causality from DOW to DAX strengthened after the announcement of FED chair in May 2013 that they could start unwinding extraordinary monetary stimulus.

Figure 2: Filter Probability of DAX Return Granger-causing DOW Return

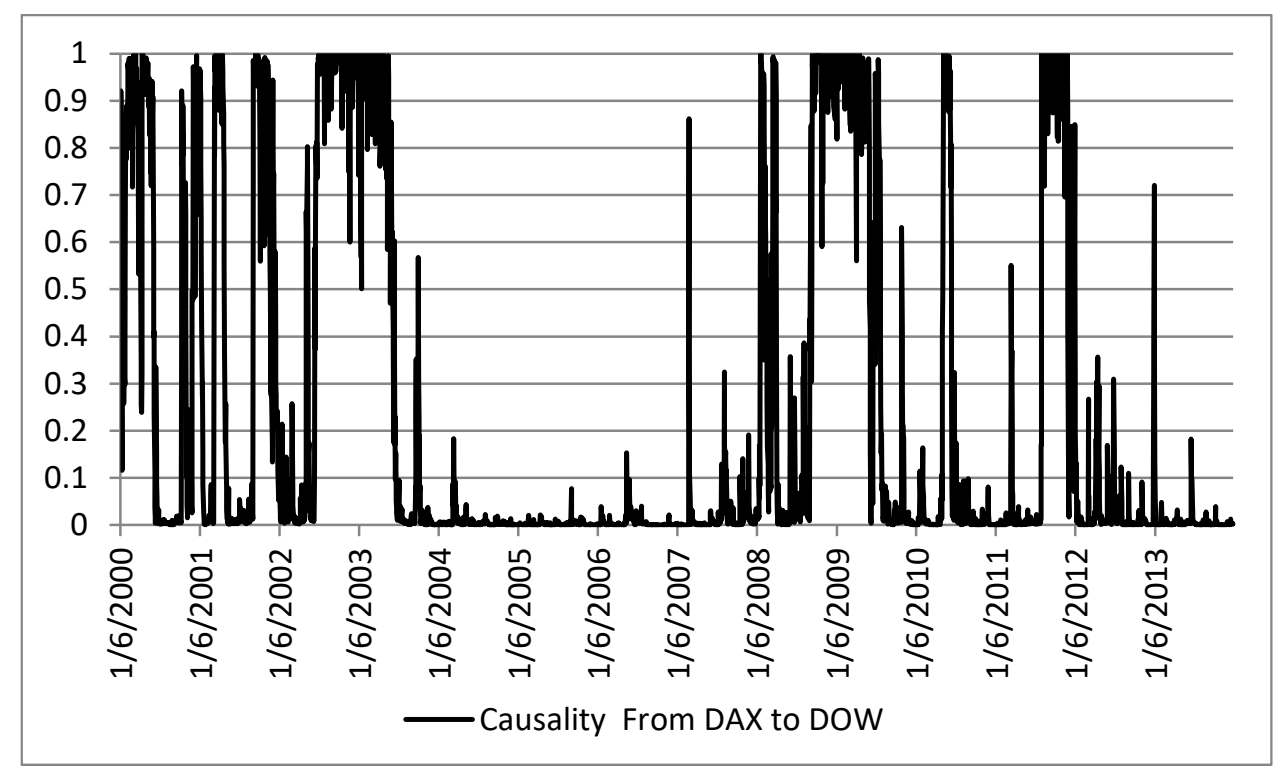

Next, we examine the causality from DAX to DOW. The plot of the estimated filter probability of DAX Granger causing DOW is shown in Figure 2. It is evident from Figure 2 that DAX does not Granger cause DOW. Nevertheless, causality is time-varying and increases in some periods. Due to increased financial and economic integration, causality from DAX to DOW is higher in the global financial crisis period and Greek crisis period (May-June 2010).

\section{3.b. Dynamic causality between the US and Japanese equity markets}

There is unidirectional Granger causality running from DOW to NIKKEI. The parameters which show the causality running from NIKKEI return to DOW return are not significantly different from zero. This finding indicates that NIKKEI return does not significantly Granger cause DOW return when the $\mathrm{St}=1$ or $\mathrm{St}=3$ prevails in the economy. On the other hand, there is significant causality 
Yönetim ve Ekonomi Araștırmaları Dergisi / Journal of Management and Economics Research Cilt/Volume: 15 Sayı/Issue: Özel Sayı 1/Special Issue 1 Aralık/December 2017 ss./pp. 1-14 M. Türkay, A. Özün Doi: http://dx.doi.org/10.11611/yead.373435

running from DOW return to NIKKEI return. Thus, DOW has predictive ability for NIKKEI when the economy is in $\mathrm{St}=1$ or $\mathrm{St}=2$.

Table 2: Estimates of Parameters of the Model for DOW and NIKKEI

\begin{tabular}{|c|c|c|c|c|c|}
\hline Parameter & Estimate & Std. error & Parameter & Estimate & Std. error \\
\hline$p_{11}^{(1)}$ & $0.964 * * *$ & 0.013 & $p_{11}^{(2)}$ & $0.980 * * *$ & 0.006 \\
\hline$p_{00}^{(1)}$ & $0.994 * * *$ & 0.002 & $p_{00^{(2)}}$ & $0.981 * * *$ & 0.006 \\
\hline$\mu_{10}$ & 0.001 & 0.000 & $\mu_{20}$ & $-0.001 * *$ & 0.000 \\
\hline$\mu_{11}$ & $-0.001 * * *$ & 0.001 & $\mu_{21}$ & 0.001 & 0.000 \\
\hline$\phi_{10^{(1)}}$ & $-0.054 * *$ & 0.014 & $\phi_{20}^{(1)}$ & $-0.121 * *$ & 0.033 \\
\hline$\phi_{10^{(2)}}$ & -0.000 & 0.008 & $\phi_{20^{(2)}}$ & $0.023 * *$ & 0.039 \\
\hline$\phi_{11}^{(1)}$ & -0.006 & 0.007 & $\phi_{2 I^{(I)}}$ & -0.123 & 0.024 \\
\hline$\phi_{10^{(2)}}$ & -0.129 & 0.057 & $\phi_{2 I^{(2)}}$ & -0.041 & 0.040 \\
\hline$\gamma_{I}^{(l)}$ & 0.003 & 0.010 & $\gamma_{2}{ }^{(1)}$ & $0.596 * * *$ & 0.053 \\
\hline$\gamma_{I}^{(2)}$ & 0.006 & 0.012 & $\gamma_{2}^{(2)}$ & 0.487 & 0.028 \\
\hline$\theta_{10^{(1)}}$ & $-0.002 *$ & 0.003 & $\theta_{20}(1)$ & $-0.099 * * *$ & 0.006 \\
\hline$\theta_{10^{(2)}}$ & $0.004 *$ & 0.003 & $\theta_{20^{(2)}}$ & $-0.023 * * *$ & 0.012 \\
\hline$\theta_{11}^{(1)}$ & -0.099 & 0.006 & $\theta_{2 I^{(1)}}$ & $-0.011 * * *$ & 0.005 \\
\hline$\theta_{11}^{(2)}$ & $-0.023^{*}$ & 0.012 & $\theta_{2 I^{(2)}}$ & -0.005 & 0.010 \\
\hline$\sigma_{11}^{(1)}$ & $0.038 * * *$ & 0.004 & $\sigma_{22}^{(1)}$ & $0.045 * * *$ & 0.005 \\
\hline$\sigma_{11}^{(2)}$ & $0.006 * * *$ & 0.000 & $\sigma_{22}^{(2)}$ & $0.010 * * *$ & 0.000 \\
\hline$\sigma_{11}^{(3)}$ & $0.021 * * *$ & 0.001 & $\sigma_{22}{ }^{(3)}$ & $0.020^{*}$ & 0.001 \\
\hline$\sigma_{11}^{(4)}$ & $0.012 * * *$ & 0.000 & $\sigma_{22}^{(4)}$ & $0.014 * * *$ & 0.000 \\
\hline Log likelihood = & 20086. & & & & \\
\hline
\end{tabular}

Notes: $* * *, * * *$ denote significance at the $10 \%, 5 \%$ and $1 \%$ levels.

We now examine the causality from DOW return to NIKKEI return. The plot of the estimated filter probability of DOW return Granger causing NIKKEI return is shown in Figure 3. It is evident from Figure 3 that DOW return Granger causes NIKKEI return, but it is time-varying. Causality from DOW to NIKKEI is weak between 2000 and 2003 but is stronger between 2004 and 2007. Causality seems to be weak in the global financial crisis period but increases thereafter. 
Yönetim ve Ekonomi Araștırmaları Dergisi / Journal of Management and Economics Research
Cilt/Volume: 15 Sayı/Issue: Özel Sayı 1/Special Issue 1 Aralık/December 2017 ss./pp. 1-14

M. Türkay, A. Özün Doi: http://dx.doi.org/10.11611/yead.373435

Figure 3: Filter Probability of DOW Return Granger-causing NIKKEI Return

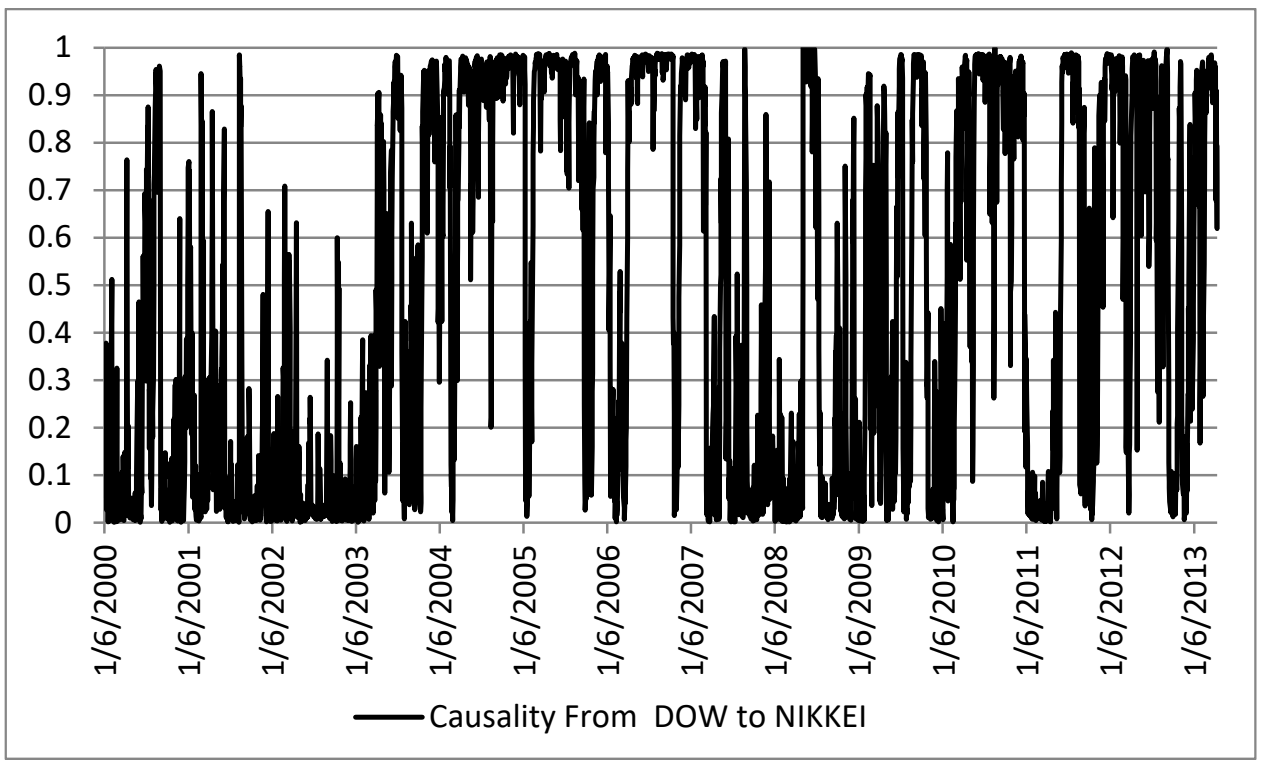

Figure 4 shows the plot of estimated filter probability of NIKKEI return Granger causing DOW return. Causality from NIKKEI to DOW is weak in the analysis period.

Figure 4: Filter Probability of NIKKEI Return Granger-causing DOW Return

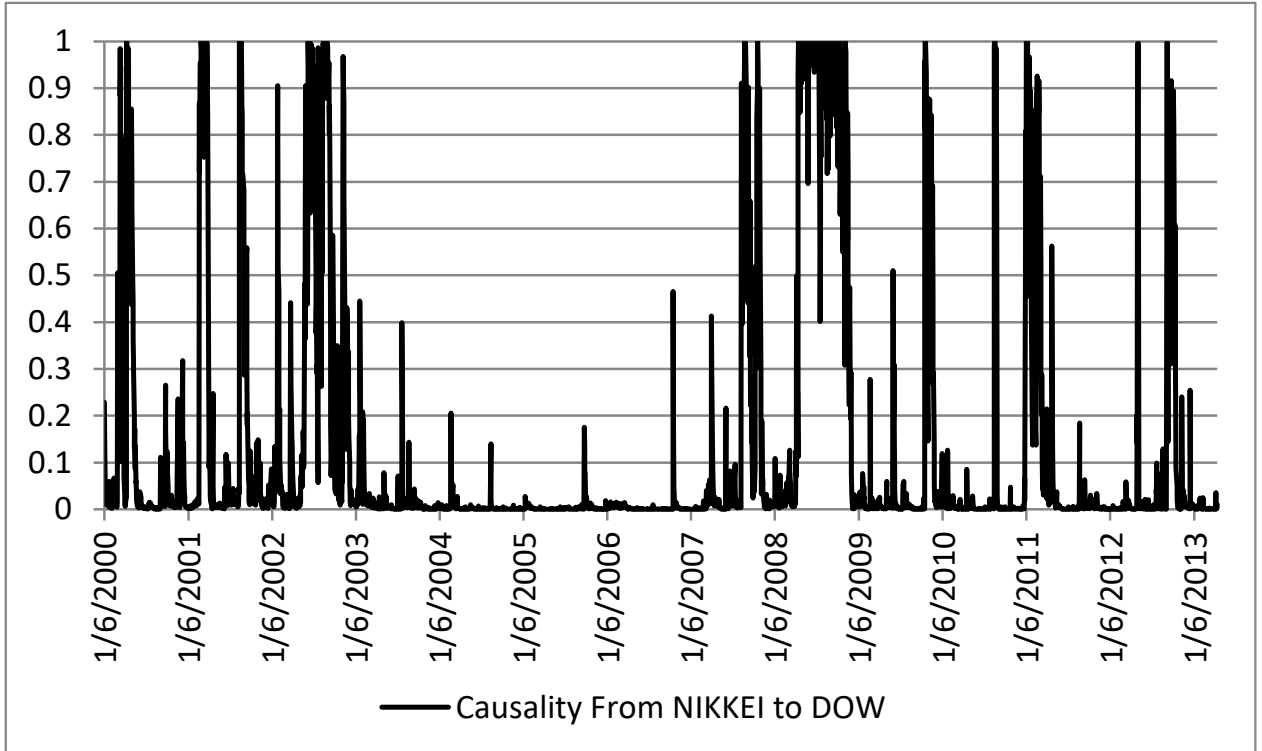

One important finding is that causality from DOW to DAX is stronger compared to the causality from DOW to NIKKEI. This is in line with closer economic and financial relations between US and Europe. 
Yönetim ve Ekonomi Araștırmaları Dergisi / Journal of Management and Economics Research

Cilt/Volume: 15 Sayı/Issue: Özel Sayı 1/Special Issue 1 Aralık/December 2017 ss./pp. 1-14

M. Türkay, A. Özün Doi: http://dx.doi.org/10.11611/yead.373435

\section{CONCLUSION}

In this paper, we tested the existence of causality relationship between the US and German, and the US and Japanese equity markets with a controlling variable selected as world volatility index (VIX). The empirical evidence shows the fact that there exists a dynamic causality between the US and German markets. The causality increases in crisis period. On the other hand, the causality relationship between the US and Japanese equity markets are time-varying. It is weak in crisis time but increases after the crisis.

The paper is the first empirical research to apply the Markov autoregression process to detect any causality from the US markets to the rest in crisis period. In the future research, the process can be applied for alternative financial instruments in different markets. Apart from extension of the process to the alternative markets, a new Markov autoregressive model based on panel data analysis can be constructed to make a generalization for a dynamic causality in the world equity markets.

\section{REFERENCES}

Ahlgren, N. and Antell, J. (2002) "Testing for Cointegration Between International Stock Prices", Applied Financial Economics, Vol. 12 No. 12, pp. 851-61.

Arshanapalli, B. and Doukas, J. (1993) "International Stock Market Linkages: Evidence from The PreAnd Post-October 1987 Period”, Journal of Banking and Finance, 17, 193- 208.

Asgharian, H., Hess, W. and Liu, L. (2013) "A Spatial Analysis of International Stock Market Linkages", Journal of Banking \& Finance, 37, 4738-4754.

Baek, E. and Brock, W. (1992) “A General Test for Non-Linear Granger Causality: Bivariate Model”, Working Paper, Iowa State University and University of Wisconsin, Madison, WI.

Becker, K.G, Finnerty, J.E. and Gupta, M. (1990) "The Intertemporal Relation Between The US and Japanese Stock Markets", Journal of Finance, 45, 1297-306.

Beine, M., Capelle-Blancard, G. and Raymond, H. (2008) "International Nonlinear Causality Between Stock Markets", The European Journal of Finance, Vol. 14, No. 8, 663-686.

Bessler, D. and Yang, J. (2003) "The Structure of Interdependence In International Stock Markets", Journal of International Money and Finance, 22, 261-287.

Caraiani, Petre (2012) "Nonlinear Dynamics in CEE Stock Markets Indices", Economic Letters, 114, $329-331$. 
Yönetim ve Ekonomi Araștırmaları Dergisi / Journal of Management and Economics Research

Cilt/Volume: 15 Sayı/Issue: Özel Sayı 1/Special Issue 1 Aralık/December 2017 ss./pp. 1-14

M. Türkay, A. Özün Doi: http://dx.doi.org/10.11611/yead.373435

Claudio Morana, Andrea Beltratti (2008) "Comovements In International Stock Markets", Int. Fin. Markets, Inst. and Money, 18 (2008), 31-45

Climent, F. and Meneu, V. (2003) "Has 1997 Asian Crisis Increased Information Flows Between International Markets", International Review of Economics and Finance, 12, 111-143.

Eun, C. S. and Shim, S. (1989) “International Transmission Of Stock Market Movements”, Journal of Financial and Quantitative Analysis, 24, 241-256.

Francis, B. and Leachman, L. (1998) "Superexogeneity And The Dynamic Linkages Among International Equity Markets”, Journal of International Money and Finance, 17, 475-492.

Granger, C. W. J. (1969) Investigating Causal Relations by Econometric Models and Cross-spectral Methods, Econometrica, 37 (3): 424-438

Gooijer,J. and Sivarajasingham, S. (2008) "Parametric And Nonparametric Granger Causality Testing: Linkages Between International Stock Markets", Physica A: Statistical Mechanics and its Applications, 387, 2547-2560

Gupta, R. and Guidi, F. (2012) "Cointegration Relationship And Time Varying Co-Movements Among Indian And Asian Developed Stock Markets”, International Review of Financial Analysis, 21, $10-22$.

Hamori, S. and Imamura, Y. (2000) "International Transmission of Stock Prices Among G7 Countries: LA-VAR Approach". Applied Economics Letters, Vol. 7 No. 9, pp. 613-8.

Hatemi, Abdulnasser (2012) "Is The UAE Stock Market Integrated with The USA Stock Market? New Evidence from Asymmetric Causality Testing”, Research in International Business and Finance, 26, 273-280.

Huang, B., Yang, C. and Hu, J. (2000) "Causality And Cointegration Of Stock Markets Among The United States, Japan, And The South China Growth Triangle”, International Review of Financial Analysis, 9:3, 281-297.

Kanas, A. (1998) "Linkages Between The US and European Equity Markets - Further Evidence From Cointegration Tests", Applied Financial Economics, 8(6), 607-614.

Kasa, K. (1992) “Common Stochastic Trends In International Stock Markets”, Journal of Monetary Economics, 29, 95-124.

Kwan, A. C. C., Sim, A. B. and Cotsomitis, J. A. (1995) "The Causal Relationships Between Equity Indices on World Exchanges", Applied Economics, 27, 33-37. 
Yönetim ve Ekonomi Araștırmaları Dergisi / Journal of Management and Economics Research

Cilt/Volume: 15 Sayı/Issue: Özel Sayı 1/Special Issue 1 Aralık/December 2017 ss./pp. 1-14

M. Türkay, A. Özün Doi: http://dx.doi.org/10.11611/yead.373435

Lee, Keun Yeong (2005) “The Contemporaneous Interactions Between The U.S.”, Japan and Hong Kong stock markets. Economic Letters, 90, 21-27.

Liu, Lu (2013) "International Stock Market Interdependence: Are Developing Markets The Same As

Developed Markets?", Int. Fin. Markets, Inst. and Money, 26, 226-238.

Longin, F. and Solnik, B. (1995) "Is The Correlation in International Equity Returns Constant: 19601990?”, Journal of International Money and Finance, 14 (1), 3-26.

Longin, F. and Solnik, B. (2001) "Extreme Correlation of International Equity Markets", The Journal of Finance, Volume 56, Issue 2, 649-676.

Malliaris, A.G. and Urrutia, J. (1992) "The international Crash of October 1987: Causality Tests", Journal of Financial and Quantitative Analysis, 27(3), 353-364.

Masih, A.M.M. and Masih, R. (1997) "Dynamic Linkages and The Propagation Mechanism Driving Major International Stock Markets: An Analysis Of The Pre And Post-Crash Eras", Quarterly Review of Economic Finance, 37, 859-885.

Masih, A.M.M. and Masih, R. (1999) "Are Asian Stock Market Fluctuations Due Mainly to IntraRegional Contagion Effects? Evidence Based on Asian Emerging Stock Markets", PacificBasin Finance Journal, Vol. 7 No 3-4, pp. 251-82.

Morana, C. and Beltratti, A. (2008) "Comovements in International Stock Markets", Int. Fin. Markets, Inst. and Money, 18, 31-45.

Narayan, P., Smyth, R. and Nandha, M. (2004) "Interdependence And Dynamic Linkages Between The Emerging Stock Markets of South Asia”, Accounting and Finance, 44, 419-439.

Ozdemir, Z. A. and Cakan, E. (2007) "Non-Linear Dynamic Linkages in The International Stock Markets", Physica A, 377, 173-180.

Psaradakis, Z., Ravn, M. and Sola, M. (2005) "Markov Switching Causality and The Money - Output Relationship", Journal of Applied Econometrics, 20(5); 665-683.

Quinn, D. and Voth, H. (2008) “A Century of Global Equity Market Correlation", The American Economic Review, Vol. 98, No. 2, 535-540.

Rua, A. and Nunes, L. (2009) "International Comovement of Stock Market Returns: A Wavelet Analysis", Journal of Empirical Finance, 16, 632-639.

Syriopoulos, T. (2004) "International Portfolio Diversification to Central European Stock Markets", Applied Financial Economics, Vol. 14 No. 17, pp. 1253-68. 
Yönetim ve Ekonomi Araștırmaları Dergisi / Journal of Management and Economics Research

Cilt/Volume: 15 Sayı/Issue: Özel Sayı 1/Special Issue 1 Aralık/December 2017 ss./pp. 1-14

M. Türkay, A. Özün Doi: http://dx.doi.org/10.11611/yead.373435

Syriopoulos, T. (2007) "Dynamic Linkages Between Emerging Europe and Developed Stock Markets:

Has The EMU Any Impact?", International Review of Financial Analysis,16,41-60.

Wang, Lihong (2014) "Who Moves East Asian Stock Markets? The Role of The 2007-2009 Global

Financial Crisis", Int. Fin. Markets, Inst. and Money, 28, 182-203.

Ye, George L. (2014) “The Interactions Between China and US Stock Markets: New Perspectives”, Int. Fin. Markets, Inst. and Money, 31, 331-342.

Zhang, B. and Li, X. (2014) "Has There Been Any Change in The Comovement Between The Chinese And US Stock Markets?", International Review of Economics and Finance, 29, 525-536. 